\title{
PERÍMETRO URBANO NO MUNICÍPIO DE CODÓ-MA
}

\section{THE CAPTURE OF A SWARM OF AFRICANIZED BEES IN THE URBAN AREA OF THE COINTY OF CODÓ-MA}

João Paulo da Silva Sousa ${ }^{1}$; Jucigleice Pascoal Salgado²; Alex Jhonne Barbosa Carvalho $^{3}$; Raimundo Nonato Moraes Costa ${ }^{4}$; Gláucio Sousa Martins ${ }^{5}$.

DOI: https://doi.org/10.31692/978-65-991061-7-0.469-470

\section{INTRODUÇÃO}

A grande quantidade de plantas apícolas utilizadas no processo de arborização das cidades e com períodos de floração distribuídos equitativamente durante o ano, principalmente nas épocas de escassez de alimento, favorecem sua migração para esses locais (TOLEDO et al., 1998; BARBOSA, 2015).

O objetivo foi realiza uma captura de um exame no perímetro urbano no bairro São Francisco no município de Codó-Ma, onde tivemos a oportunidade de vivencia as dificuldades de realiza uma captura na área.

\section{RELATO DE EXPERIÊNCIA}

A atividade de coleta do enxame aconteceu em uma pequena estrutura de taipa em um pátio de uma frota de ônibus realizado no barro São Francisco na cidade de Codó interior do estado do maranhão como mostra a figura 1(A). A captura foi realizada pela equipe de apicultura do instituto federal do maranhão IFMA-Campus Codó. A retirada do enxame tinha que sem rápida e precisa, pois, ficava ao lado de uma rua com um fluxo intenso e o dono do estabelecimento relatava que as abelhas já estavam prejudicando o ambiente de trabalho. Para realiza a captura do enxame fora utilizado um (1) caixa de coleta de simples, uma (1) faca, um (1) fumegado, um (1) balde, palha de arroz, borracha elástica, quatro (4) roupas de apicultor, uma (1) caixa fosforo.

O enxame estava localizado abaixo de uma porta antiga apoiada em um pneu velho, a princípio a coleta do enxame seria rápida e simples, mais ao fazermos o levantamento da porta que estava apoiada no pneu notamos algo diferente as abelhas tinham utilizado a porta e logo em seguida os espaços dentro do pneu para aumenta sua colmeia como mostra a figura 1(B), logo em seguida começamos a transferi a colmeia para a caixa de abelhas simples na

\footnotetext{
${ }^{1}$ Licenciatura em Ciências Agrárias, IFMA /Campus Codó, joaopauloneto1.00@gmail.com

2 Engenharia Florestal, UFRA/Capitão Poço, juci.pier@ hotmail.com

${ }^{3}$ Bacharel em Agronomia, UFMA/Campus Codó, alex.jbc@ifma.edu.br

${ }^{4}$ Licenciatura em Ciências Agrárias, IFMA /Campus Codó, raimundo.costa@ifma.edu.br

${ }^{5}$ Licenciatura em Informática, UFMA/Campus Codó, glauciosmartins@gmail.com
} 
transferência conseguimos algo raro em uma captura, localiza a rainha e conseguimos inseri ela na caixa com todo cuidado como mostra a figura 1(C), após conseguir inseri a rainha na caixa começamos a encaixa as crias e os favos no seu novo espaço de vivencia como mostra a figura 1(D). A captura foi de suma importância pois conseguimos observas que os enxames em áreas urbanas têm um grau de dificultada muitas das vezes difíceis de se apanhar e muitas das vezes colocando em risco a segurança da população em um procedimento mal realizado pelos coletores dos enxames, essa captura fio realizada com sucesso não teve nenhuma ocorrência de ferroadas em moradores ou pedestre que transitava no momento.

Imagem 1: Atividade Experimental. Fonte: Própria
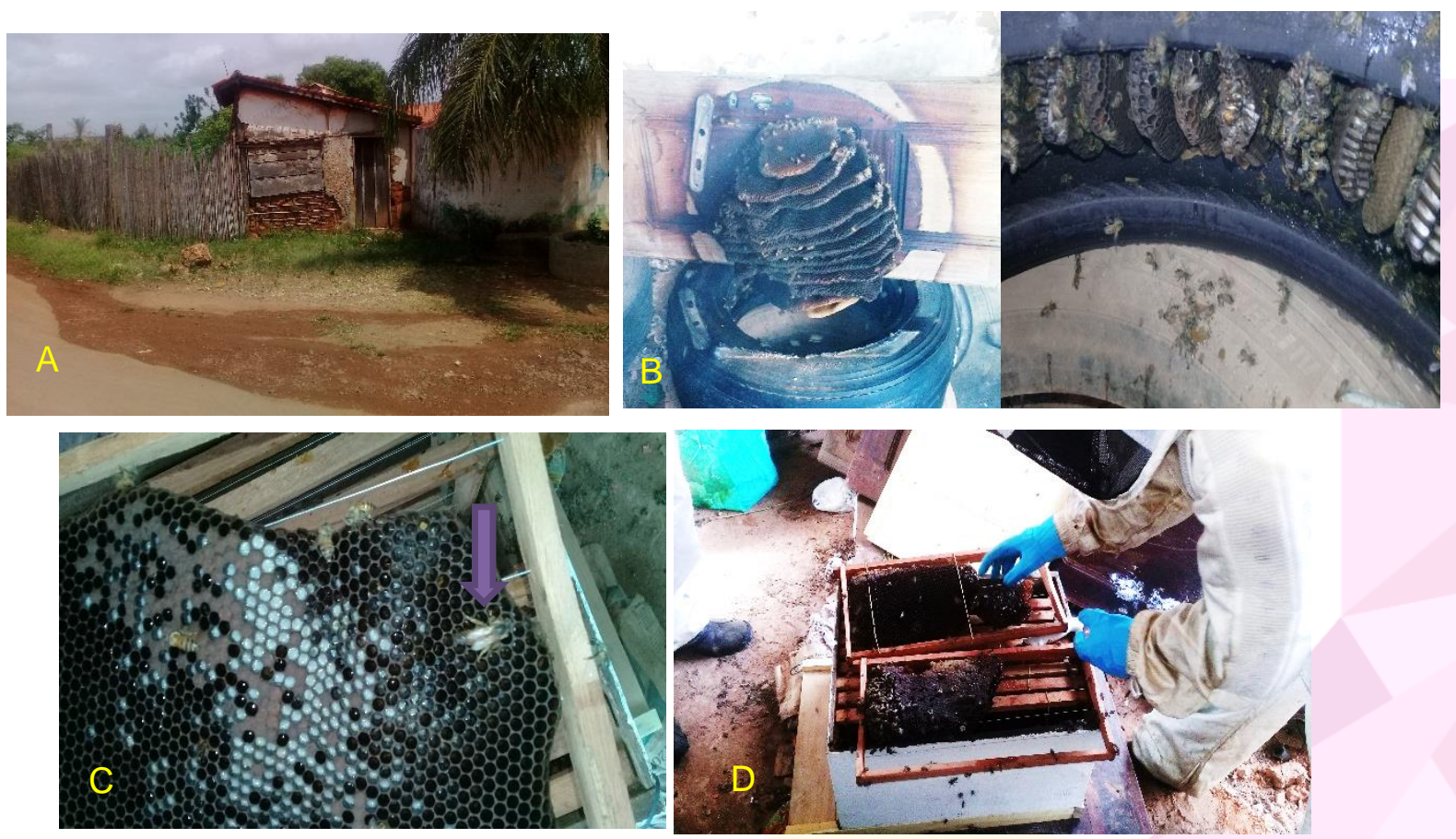

\section{CONSIDERAÇÕES}

Durante a realização da captura do enxame foram registadas no momento mais dois enxames próximos, com isso chegamos à conclusão que é medida em que a área urbana vai expandido a tendência é que os exames se alojem nessas áreas pela vasta quantidade de espécies arbóreas frutíferas. Com isso Torna-se indispensável à manutenção da coleta de enxames em áreas urbanas prevenirem acidentes e dar destinação adequada aos enxames.

\section{REFERÊNCIAS}

BARBOSA, C.A.F; VIEIRA, G.H.C; CONTROLE DE ABELHAS EM ÁREAS

URBANAS. Disponível em < file:///C:/Users/CPPPE/Downloads/252-266-1-

PB\%20(4).PDF>. Acesso em 23 de set.2018. 